(C) Dereito Vol.29, n01:95-107 (Xaneiro-Xuño, 2020) • ISSN 1132-9947

\title{
A RECLAMAÇÃo GRACIOSA NO CONTEXTO DO DIREITO PROCEDIMENTAL TRIBUTÁRIO PORTUGUÊS
}

La reclamación en el contexto del Derecho Procesal Fiscal Portugués

DOI: http://dx.doi.org/10.15304/dereito.29.1.6276

\author{
JosÉ DE CAMPOS AMORIM \\ Professor Coordenador \\ ISCAP-Politécnico do Porto \\ j.camposamorim@gmail.com \\ Patrícia Anjos AzeVedo \\ Professora Adjunta Convidada \\ ESTG-Politécnico do Porto \\ patricia_anjos_azevedo86@hotmail.com
}

\section{Resumen}

El contribuyente tiene un conjunto de medios de defensa de sus derechos e intereses legalmente protegidos, que el legislador portugués ha estado reforzando en el procedimiento y proceso tributario. Para prevenir y prevenir acciones u omisiones de la administración tributaria que podrían dañar los derechos e intereses legítimos de los contribuyentes, los contribuyentes pueden, en particular, y en el curso de los procedimientos, hacer una reclamación.

Palabras clave: Medios de defensa; procedimiento tributario; reclamación.

\section{Abstract}

The taxpayer has a set of means of defense of his rights and interests legally protected, which the Portuguese legislator has been reinforcing in the tax procedure and process. In order to prevent and prevent actions or omissions of the tax authorities that could harm taxpayers' legitimate rights and interests, taxpayers may, in particular, as regards the procedure, make a gracious complaint.

Keywords: Means of defense; tax procedure; administrative complaint.

\section{Resumo}

O contribuinte dispõe de um conjunto de meios de defesa dos seus direitos e interesses legalmente protegidos, que o legislador português tem vindo a reforçar no âmbito do procedimento e processo tributário. Para prevenir e evitar ações ou omissões da Autoridade Tributária e Aduaneira suscetíveis de lesar os direitos e interesses legítimos dos contribuintes, estes podem, nomeadamente, no que toca ao procedimento, recorrer à reclamação graciosa.

Palavras-Chave: Meios de defesa; procedimento tributário; reclamação graciosa.

Recibido: 20/06/2020. Aceptado: 16/07/2020. 


\section{SUMÁRIO}

1.- INTRODUÇÃO; ; 2.- PROCEDIMENTO DE RECLAMAÇÃO GRACIOSA.; 2.1.- Considerações gerais.; 2.2.- Fundamentos da reclamação graciosa.; 2.3.- Tramitação da reclamação graciosa.; 2.4.- Casos de reclamação graciosa necessária prévia à via judicial.; 2.5.- Articulação entre a reclamação graciosa e a impugnação judicial.; 3.- CONCLUSÕES.; 4.BIBLIOGRAFIA.

\section{SUMMARY}

1.- INTRODUCTION.; 2.- ADMINISTRATIVE COMPLAINT PROCEDURE.; 2.1.- General considerations.; 2.2.- Grounds of the administrative complaint.; 2.3.- Administraitve complaint processing.; 2.4. -Gracious complaint cases required prior to legal action.; 2.5.- Link between the administrative complaint and the legal action.; 3.- CONCLUSIONS.; 4.BIBLIOGRAPHY.

\section{SUMARIO}

1.- INTRODUCCIÓN.; 2.- PROCEDIMIENTO DE LA RECLAMACIÓN.; 2.1.Consideraciones generales.; 2.2.- Motivos de la reclamación.; 2.3.Procesamiento de la reclamación.; 2.4.- Casos de reclamación previa a la impugnación judicial.; 2.5.- Relación entre la reclamación y la impugnación judicial. ; 3.- CONCLUSIONES.; 4.- BIBLIOGRAFÍA.

\section{INTRODUÇÃo}

A reclamação graciosa é um importante instrumento de proteção dos direitos e interesses dos contribuintes, destinado a reapreciar os atos praticadas pela Autoridade Tributária e Aduaneira (AT), independentemente do valor da causa e das questões jurídicas suscitadas1. Não existe no procedimento administrativo o chamado efeito de caso julgado, que carateriza a fase judicial. Contudo, este meio procedimental não dispensa o contribuinte do pagamento do tributo, sob pena de a AT recorrer ao processo de execução fiscal.

Pode dar-se o caso de o contribuinte lançar mão, ao mesmo tempo, de meios procedimentais e processuais que tenham por objeto a apreciação da legalidade do ato tributário. Neste caso, e a título de exemplo, o Código de Procedimento e de Processo Tributário (CPPT) proíbe a dedução da reclamação graciosa quando já tiver sido instaurada impugnação judicial com o mesmo fundamento, dando prevalência ao processo judicial.

Os fundamentos para interposição da reclamação graciosa são os mesmos aplicáveis à impugnação judicial. Tal significa que o contribuinte pode apresentar a reclamação graciosa e, antes da sua decisão ou da formação do indeferimento tácito, pode impugnar diretamente o ato de liquidação, desde que o faça durante o prazo previsto para a impugnação, não esperando que seja proferida a respetiva decisão administrativa.

1 Caso se suscitem questões de Direito perante a AT, estas deverão ser apresentadas por um mandatário tributário, que poderá ser um advogado, um advogado-estagiário ou um solicitador (cfr. art. ${ }^{5}$ 5. ${ }^{\circ}$ n. ${ }^{\circ} 2$ do CPPT). 
Contudo, em alguns casos, a lei exige que, antes de recorrer à via judicial, o contribuinte tenha que necessariamente apresentar uma reclamação graciosa. Há, assim, situações em que é necessário esgotar primeiramente a via administrativa antes de deduzir a impugnação judicial. A existência desta reclamação necessária justifica-se pela necessidade de filtrar certos atos previamente à via judicial. Nos casos em que a lei exige a reclamação necessária, o contribuinte não pode optar diretamente pela via da judicial.

\section{PROCEDIMENTO DE RECLAMAÇÃO GRACIOSA}

\subsection{Considerações gerais}

A reclamação graciosa é um meio impugnatório através do qual o sujeito passivo (o contribuinte, o substituto ou o responsável tributário) requer a anulação (total ou parcial) de um ato tributário, com fundamento em qualquer ilegalidade - art. ${ }^{\circ} 68 .^{\circ}$ do CPPT -, incluindo-se os casos de inexistência ou de nulidade de atos tributários. A reclamação graciosa tem em vista a reapreciação do ato tributário pela própria entidade que o praticou. Esta reclamação pode ser apresentada independentemente do valor da causa e suscitar ou não questões de Direito. Caso se suscitem questões de Direito perante a AT, estas deverão ser apresentadas por um mandatário tributário, que poderá ser um advogado, um advogadoestagiário ou um solicitador (cfr. art. ${ }^{\circ} 5 .{ }^{\circ}, \mathrm{n} .{ }^{\circ} 2$ do CPPT).

O procedimento de reclamação graciosa é, segundo o art. ${ }^{\circ} 69 .{ }^{\circ}$, alínea a) do CPPT, de natureza simples e relativamente célere, uma vez que dispensa formalidades essenciais - alínea b), bem como limita os meios probatórios à prova documental - cfr. alínea e) da mesma disposição. De acordo com o art. ${ }^{\circ}$ 69.0, alínea b) do CPPT, nenhuma das formalidades essenciais exigidas no art. ${ }^{\circ} 102 .^{\circ}$ do Código do Procedimento Administrativo (CPA) para a apresentação da reclamação graciosa deverá ser considerada essencial.

Quanto aos meios de prova, a reclamação graciosa encontra-se limitada à prova documental, ao contrário da impugnação judicial que inclui, para além dos meios gerais de prova, a prova testemunhal e a prova pericial. Por isso, se o contribuinte necessitar de apresentar meios de prova distintos da prova documental deverá optar pela apresentação da impugnação judicial em vez da reclamação judicial. No âmbito da reclamação graciosa, o órgão instrutor pode ainda ordenar outras diligências complementares indispensáveis à descoberta da verdade material, como a audição de testemunhas para o esclarecimento dos factos praticados.

Ainda em termos distintivos, não existe, na fase do procedimento administrativo o chamado efeito de caso julgado [na terminologia da alínea c) do art. ${ }^{\circ}$ 69.0 do CPPT, não existe "caso decidido ou resolvido"]2, que seria aplicável numa fase judicial (ou de processo), o que significa que a decisão pode ser objeto de recurso hierárquico, de impugnação

2 SOUSA, J. L., Código de Procedimento e de Processo Tributário Anotado e Comentado, vol. I, Áreas Editora, p. 633-636, 2011. 
judicial ou de recurso para o tribunal arbitral. De facto, o deferimento ou indeferimento da reclamação graciosa consubstancia um ato administrativo, mas não faz, contudo, caso julgado, apenas constitui um caso julgado administrativo, que pode ser objeto de impugnação judicial ou de execução em processo de execução de julgados.

A reclamação graciosa tem também a particularidade de estar isenta de custas, pois na fase administrativa as custas não são devidas (salvo se a pretensão do contribuinte estiver destituída de qualquer fundamento, caso em que o reclamante fica obrigado a um agravamento à coleta correspondente a $5 \%$ do valor em causa, uma vez que tal é entendido como "litigância de má fé" - cfr. art. ${ }^{\circ} 77.0^{\circ}$, n. ${ }^{\circ} 1$ do CPPT e art. ${ }^{\circ} 456 .{ }^{\circ}$, n. ${ }^{\circ} 2$ do Código do Processo Civil - $\left.\mathrm{CPC}\right)_{3}$, contrariamente à fase judicial em que são exigidas custas judiciais - cfr. alínea d) do art. ${ }^{\circ}$ 69.0 do CPPT - e a constituição de mandatário judicial nas causas judiciais cujo valor exceda o dobro da alçada do tribunal tributário de primeira instância ( $€ 10.000)$, bem como nos processos da competência do Tribunal Central Administrativo (TCA) e do Supremo Tribunal Administrativo (STA) - cfr. art. ${ }^{\circ} 6 .{ }^{\circ}$, n. ${ }^{\circ} 1$ do CPPT. Contudo, a reclamação requer o cumprimento de certas formalidades legalmente consagradas, designadamente o exercício de direito de audição, a clareza e compreensibilidade da petição, a fundamentação da decisão e a notificação do interessado - vejam-se os art. ${ }^{\circ}$ s 267. ${ }^{\circ}$, n. ${ }^{\circ} 5$ e 268. ${ }^{\circ}$, n. ${ }^{\circ} 3$ da Constituição da República Portuguesa (CRP), e os art. ${ }^{\circ} \mathrm{s} 60 .{ }^{\circ}$, n. $^{\circ} 1$, alínea b) e $77 .{ }^{\circ}$ da Lei Geral Tributária (LGT).

De referir ainda que, de acordo com a alínea f) do art. ${ }^{\circ} 69 .{ }^{\circ}$ do CPPT, a reclamação graciosa não apresenta caráter suspensivo da liquidação, exceto quando seja prestada garantia adequada, nos termos do art.o 199.0 do CPPT. Tal significa que o contribuinte deve proceder ao pagamento do tributo, sob pena de entrar em execução fiscal. A inexistência de efeito suspensivo faz com que a administração possa dar execução ao ato objeto de reclamação. No que se refere à prestação de garantia4, esta deve ser prestada a requerimento do contribuinte, no

3 A finalidade deste agravamento à coleta é dissuadir os interessados de deduzirem reclamações graciosas sem qualquer fundamento. Este agravamento pode ser objeto de "impugnação judicial autónoma, com fundamento na injustiça da decisão condenatória" (cfr. n. ${ }^{3} 3$ do art. $077 .{ }^{\circ}$ do CPPT). No caso de a reclamação graciosa ser condição necessária para a interposição de impugnação judicial, o agravamento só é exigível caso tenha sido julgada improcedente a impugnação judicial deduzida pelo reclamante (cfr. n. 02 do art. $077.0^{\circ}$ do CPPT). Assim, se o tribunal não anular o ato tributário impugnado, o agravamento aplicar-se-á, a título de custas.

4 Esta garantia pode consistir numa garantia bancária, caução, seguro-caução ou qualquer outro meio suscetível de assegurar os créditos da AT, nomeadamente a fiança. Esta garantia deve respeitar o princípio da proporcionalidade, devendo restringir-se ao necessário para atingir o fim pretendido, isto é, o seu montante deve ter por referência o valor da dívida, dos juros e das custas, acrescido de $25 \%$ da soma daqueles valores. Por outro lado, esta garantia deve estar limitada a um determinado período. Assim, por exemplo, a garantia prestada para suspender e processo de execução fiscal caduca se a reclamação graciosa não estiver decidida no prazo de um ano a contar da data da sua interposição, salvo se este atraso resultar de motivo imputável ao reclamante - art. ${ }^{\circ}$ 183. ${ }^{\circ}-A$, n. ${ }^{\circ}$ s 1 e 2 do CPPT. A verificação da caducidade deve ser requerida pelo 
prazo de 10 dias a contar da notificação do órgão periférico local competente [cfr. al. f) do art. 69. ${ }^{\circ}$. Esta garantia caduca se a reclamação graciosa não estiver decidida no prazo de 1 ano a contar da sua interposição - cfr. art. o 183. ${ }^{\circ}$-A do CPPT.

A instauração da reclamação graciosa é causa interruptiva do prazo de prescrição da obrigação tributária (cfr. art. ${ }^{\circ} 49 .^{\circ}$, n. ${ }^{\circ} 1$ da LGT), interrompendo também o prazo para a interposição da impugnação judicial, uma vez que é possível utilizar este meio processual após o indeferimento da primeira (cfr. art. 0 102.0, n. ${ }^{\circ} 2$ do CPPT).

Regra geral, a reclamação graciosa é facultativa, mas há situações em que é necessária para deduzir a impugnação judicial, a saber: erro na autoliquidação (art.o $131 .^{\circ}$ do CPPT); erro na retenção na fonte (art.o 132.0 do CPPT); erro nos pagamentos por conta (art.o $133 .{ }^{\circ}$ do CPPT); erro em matéria de classificação pautal, origem ou valor aduaneiro das mercadorias (art. ${ }^{\circ} 133 .^{\circ}-A$ do CPPT); e erro na quantificação da matéria tributável ou nos pressupostos de aplicação dos métodos indiretos (art.o 117. ${ }^{\circ}$ do CPPT).

A reclamação graciosa não deve confundir-se com a reclamação administrativa, sendo a primeira utilizada a propósito da apreciação da legalidade dos atos tributários e a segunda a respeito dos atos administrativos em matéria tributária. Com efeito, o prazo para a interposição da reclamação graciosa é de 120 dias (art. ${ }^{\circ} 700^{\circ}$ do CPPT), ao passo que o prazo para a interposição da reclamação administrativa é de 15 dias (art.o 191.०, n.o 3 do CPA). Verifica-se ainda que o prazo de decisão das reclamações graciosas é de 4 meses (art. 0 57.0, n.0 1 da LGT) e o prazo de decisão das reclamações administrativas é de 30 dias (art. 0 $192 .{ }^{\circ}$, n. 02 do CPA)5. Há aqui uma diferença no que respeita à contagem dos prazos: no caso dos prazos de procedimento administrativo, estes suspendem-se aos sábados, domingos e feriados, nos termos do art.o $87 . .^{\circ}$ do CPA, o que não se verifica relativamente aos prazos de procedimento tributário previstos no art. $020 .{ }^{\circ}$ do CPPT. Esta diferença resulta do facto de estarmos, por um lado, perante decisões administrativas em matéria tributária e, por outro lado, perante decisões tributárias.

interessado ao órgão com competência para decidir a reclamação. Se a decisão não for proferida no prazo de 30 dias após o requerimento do interessado, considera-se tacitamente deferido o pedido ( $n .^{\circ} \mathrm{s} 3$ e 4 do art. ${ }^{\circ} 183 .{ }^{\circ}-\mathrm{A}$ do CPPT). Em caso de deferimento expresso ou tácito, o órgão de execução fiscal deverá promover, no prazo de 5 dias, o cancelamento da garantia. Caso a garantia oferecida se venha, no futuro, a revelar insuficiente, o executado é notificado para, no prazo de 15 dias, proceder ao reforço da mesma, sob pena de a suspensão da execução deixar de produzir efeitos art. ${ }^{\circ} 199 .{ }^{\circ}$, n. ${ }^{\circ} 5$ do CPPT.

5 Nos termos deste artigo, o órgão competente pode confirmar, revogar, anular, modificar ou substituir o ato reclamado ou praticar o ato ilegalmente omitido. 


\subsection{Fundamentos da reclamação graciosa}

A reclamação graciosa é admitida para todo o tipo de atos tributários que lesem direitos ou interesses dos contribuintes6. Pode dar-se o caso de o contribuinte lançar mão, ao mesmo tempo, de meios procedimentais e processuais que tenham por objeto a apreciação da legalidade do ato tributário. $\mathrm{O}$ n. ${ }^{\circ} 2$ do art. ${ }^{\circ} 68 .^{\circ}$ do CPPT proíbe a dedução da reclamação graciosa quando já tiver sido instaurada impugnação judicial com o mesmo fundamento - cfr. n. ${ }^{\circ} 3$ e 4 do art. ${ }^{\circ} 111 .{ }^{\circ}$ do CPPT. A lei dá prevalência ao processo judicial, quer a reclamação graciosa tenha sido apresentada antes ou na pendência da impugnação judicial: (a) no caso de ter sido apresentada uma reclamação graciosa antes da impugnação judicial sobre a ilegalidade do mesmo ato tributário, tal procedimento cessa com a apresentação da impugnação, independentemente dos fundamentos neles invocados (art. ${ }^{\circ} 111 .{ }^{\circ}$, n. 03 do CPPT); (b) no caso de a reclamação graciosa ter sido apresentada na pendência da impugnação judicial, a reclamação deve ser recusada devido à prevalência do processo judicial sobre o procedimento tributário. Os procedimentos tributários deixam de prosseguir devido à existência do processo de impugnação judicial. As questões suscitadas nos procedimentos tributários que não tenham sido reproduzidas nas impugnações passam a integrar estes processos, devendo ser apreciadas pelo juiz (art. ${ }^{\circ} 111 .{ }^{\circ}, n^{\circ}{ }^{\circ} 4$ do CPPT), por razões de economia processual.

A reclamação graciosa pode ter por fundamento qualquer ilegalidade do ato de liquidação ou qualquer vício procedimental que ocorra previamente à decisão final. Os fundamentos para interposição da reclamação graciosa seguem o estabelecido no art.o $99 .{ }^{\circ}$ do CPPT, isto é, são os mesmos aplicáveis à impugnação judicial (cfr. art. ${ }^{\circ} 70.0^{\circ}$ do CPPT), a saber7:

(i) errónea qualificação e quantificação dos rendimentos, lucros, valores patrimoniais e outros factos tributários (vícios materiais) [art. ${ }^{\circ} 99 .^{\circ}$, alínea a) do CPPT]: a errónea qualificação refere-se a situações de errada qualificação jurídica dos factos tributários, sendo que a errónea quantificação está relacionada com o cálculo do imposto. A errónea qualificação sucede, por exemplo, no caso de um gasto ter sido qualificado erradamente como despesa de representação e não o ser. A errónea quantificação ocorre, por exemplo, no caso da aplicação de uma taxa que não corresponde à taxa legalmente prevista;

(ii) incompetência [art. ${ }^{9} 99 .{ }^{\circ}$, alínea b) do CPPT]: reporta-se à violação dos poderes da AT, em que uma entidade viola as normas de atribuição de competência. Este vício ocorre quando a liquidação do imposto incumbe ao órgão periférico regional e não ao órgão periférico local;

(iii) ausência ou vício da fundamentação legalmente exigida [art. 0 99. , alínea c) do CPPT]: verifica-se no caso de falta de fundamentação do ato

6 O órgão competente para decidir a reclamação graciosa é o superior hierárquico do que praticou o ato reclamado, o que nos leva a considerar que a reclamação graciosa acaba por desempenhar um papel semelhante ao do recurso hierárquico.

7 ROCHA, J. F., Lições de Procedimento e Processo Tributário, Coimbra Editora, p. 230$232,2014$. 
tributário ou quando a fundamentação não está de acordo com os requisitos legais. Tal ocorre quando, por exemplo, na notificação da liquidação não constam os requisitos substanciais previstos na lei;

(iv) preterição de outras formalidades legais [art. $099 .{ }^{\circ}$, alínea d) do CPPT]: diz respeito a situações relativas a outras questões legais suscetíveis de comprometer a legalidade do ato final. É o caso da preterição do direito de audição, previsto no art. ${ }^{\circ} 60 .{ }^{\circ}$ da LGT. A preterição do direito de audição é suscetível de gerar a anulabilidade do ato (vício formal - preterição de formalidade essencial).

Como se trata de uma enumeração não exaustiva, podem existir outros fundamentos que não estão aqui enumerados, designadamente a duplicação da coleta (quando se refira ao mesmo facto e período de tempo), a falta de notificação da liquidação, a inexistência do facto tributário (nos casos de não ocorrência do facto gerador do imposto), a caducidade do direito à liquidação (quando a AT ultrapasse o prazo de 4 anos para liquidar o respetivo tributo - art. $045 .{ }^{\circ}$ da LGT), etc.

Também não pode haver reclamação relativamente a determinado tipo de atos para os quais a lei preveja procedimentos especiais, como é o caso do procedimento de revisão da matéria coletável (art. ${ }^{\circ} 91 .{ }^{\circ}$ da LGT) e do procedimento de correção de erros da AT (art. ${ }^{\circ}$ s 95. ${ }^{\circ}-\mathrm{A}$ e ss do CPPT).

Da reclamação graciosa pode resultar um deferimento ou indeferimento expresso ou tácito. No caso de indeferimento expresso ou tácito da reclamação graciosa, o contribuinte pode interpor uma impugnação judicial, nos termos do art. ${ }^{\circ} 102 .^{\circ}$ do CPPT, sendo o prazo-regra para a interposição da impugnação judicial de 3 meses a contar dos factos previstos no art. ${ }^{\circ} 102 .^{\circ}, \mathrm{n}^{\circ} 1$ do CPPT, salvo prazos especiais fixados em alguma outra norma, como, por exemplo, art. ${ }^{\circ} 131 .^{\circ}$, n. ${ }^{\circ} 1$ do CPPT (reclamação de erro na autoliquidação, em que o prazo de impugnação é de 2 anos); art. ${ }^{\circ} 132 .^{\circ}$, n. ${ }^{\circ} 3$ do CPPT (reclamação de erro na retenção na fonte, em que o prazo de impugnação é de 2 anos); art. ${ }^{\circ} 133 .^{\circ}$, n. $^{\circ} 2$ do CPPT (pagamento por conta indevido, em que o prazo de impugnação é de 30 dias); art. ${ }^{\circ} 133 .{ }^{\circ}$, n. ${ }^{\circ} 3$ do CPPT (indeferimento expresso da reclamação, sendo o prazo de impugnação de 30 dias); art.o $133 .{ }^{\circ}$, n. ${ }^{\circ} 4$ do CPPT (reclamação tacitamente deferida, sendo o prazo de impugnação de 90 dias); art. ${ }^{\circ} 134 .{ }^{\circ}$, n. ${ }^{\circ} 1$ do CPPT (atos de fixação dos valores patrimoniais, sendo neste caso o prazo de 90 dias); art. ${ }^{134 .}{ }^{\circ}, \mathrm{n} .{ }^{\circ} 3$ do CPPT (quando o contribuinte tenha solicitado a correção do VPT constante na inscrição matricial, sendo neste caso o prazo de 30 dias); art. 143. ${ }^{\circ}$, n. ${ }^{\circ} 1$ do CPPT (atos de apreensão de bens praticados pela administração tributária, em que o prazo é de 15 dias) e art. 144.0, n. 01 do CPPT (providências cautelares adotadas pela administração tributária, em que o prazo é de 15 dias).

\subsection{Tramitação da reclamação graciosa}

A reclamação graciosa é apresentada junto do órgão periférico local da área do domicílio ou sede do contribuinte, da situação dos bens ou da liquidação, que procederá à instrução do procedimento, no prazo não 
superior a 90 dias, a partir dos elementos de que dispõe [cfr. art. ${ }^{\circ} 73 .^{\circ}$, n. ${ }^{\circ} 2$ e art. ${ }^{\circ} 69 .{ }^{\circ}$, alínea e), ambos do CPPT].

$\mathrm{Na}$ fase da instrução, juntam-se ao processo todos os elementos de que os serviços disponham e outros que os serviços possam vir a obter após a realização de diligências complementares indispensáveis à obtenção de prova complementar e consequente descoberta da verdade material [art. ${ }^{\circ}$ 73.0, n. ${ }^{\circ} 2$ e 69.0, alínea e), ambos do CPPT]. Caso o órgão periférico local disponha já de todos os elementos necessários para a tomada de decisão, está dispensado da fase de instrução (n.o 3 do art.o $73 .{ }^{\circ}$ do CPPT) e o processo segue de imediato para a decisão final. É o que sucede nos casos em que esteja em causa apenas a apreciação de uma questão de Direito. Se a instrução for realizada por um órgão diferente do órgão competente para decidir, cabe ao órgão instrutor a elaboração de um relatório definindo o conteúdo (seleção dos factos relevantes para a apreciação das questões que foram suscitadas, incluindo a argumentação utilizada pelos intervenientes) e o objeto (indicação do fim a que se propõe o procedimento, bem como as questões que devam ser apreciadas), propondo uma decisão aos interessados, que contenha uma síntese dos fundamentos de facto e de Direito da proposta de decisão. Se o valor da causa não exceder a alçada do tribunal tributário e a questão a resolver for de manifesta simplicidade, o órgão periférico local pode decidir de imediato após o fim da instrução.

Antes da decisão, a AT deve notificar o contribuinte do projeto de decisão sobre o qual apresentará os argumentos e novos elementos que considera pertinentes, para que este possa exercer o seu direito de audição, oralmente ou por escrito, num prazo não inferior a 15, nem superior a 25 dias [cfr. art. ${ }^{\circ} 60 .{ }^{\circ}$, n. ${ }^{\circ} 1$, alínea b) e n. ${ }^{\circ} 6$ da LGT].

O órgão decisor pode deferir ou indeferir expressamente o pedido do contribuinte. O deferimento expresso pode resultar na anulação total ou parcial do ato tributário, com eficácia retroativa (ex tunc), com vista a repor a situação anterior, prevendo-se a possibilidade do direito a juros indemnizatórios no caso de erro imputável à AT. $O$ indeferimento expresso, por seu turno, visa a manutenção dos efeitos do ato tributário no ordenamento jurídico.

Se o órgão competente não se pronunciar sobre a reclamação no prazo de quatro meses a partir da data de entrada nos serviços, esta presume-se indeferida tacitamente para efeitos de recurso hierárquico, recurso contencioso ou impugnação judicial (art. ${ }^{\circ} 57 .{ }^{\circ}$, n. ${ }^{\circ} 5$ da LGT, bem como art. ${ }^{\circ}$ s $76 .{ }^{\circ}, \mathrm{n} .{ }^{\circ} 1$ e $106 .{ }^{\circ}$ do CPPT). Pode ainda admitir-se a possibilidade de uma impugnação antes do decurso do prazo de formação do indeferimento tácito. Deste modo, depois de apresentar a reclamação graciosa e antes da sua decisão ou da formação do indeferimento tácito, o contribuinte pode impugnar diretamente 0 ato de liquidação, desde que 0 faça durante o prazo previsto para a impugnação. O TCA e o STA têm vindo a admitir essa possibilidade considerando que o "interessado pode optar por não esperar que seja proferida a respetiva decisão, podendo optar pela impugnação contenciosa do ato tributário impugnado, mesmo antes de estar expirado o prazo legal para ser decidida a reclamação, com 
base no citado princípio de que os prazos, não podendo ser excedidos, podem, em regra, ser antecipados, desde que já esteja praticado o ato que é objeto de impugnação"8. Restringir essa possibilidade resultaria numa limitação do princípio da tutela jurisdicional efetiva.

De notar que o n. ${ }^{\circ} 2$ do art. $68 .{ }^{\circ}$ do CPPT proíbe a dedução da reclamação graciosa quando já tiver sido instaurada impugnação judicial com 0 mesmo fundamento - cfr. n. os 3 e 4 do art. ${ }^{\circ} 111.0^{\circ}$ do CPPT. Caso o contribuinte apresente uma reclamação graciosa na pendência de impugnação judicial, a reclamação não é apreciada pela AT, sendo esta apensa ao processo de impugnação judicial, cabendo então ao Tribunal apreciar as questões suscitadas na reclamação e na impugnação - cfr. art. ${ }^{0} 111 .{ }^{\circ}$, n. 04 do CPPT.

De referir ainda que estas regras não se aplicam à reclamação graciosa que tenha como fundamento em erro na classificação pautal, origem ou valor aduaneiro das mercadorias - cfr. n. ${ }^{\circ} 7$ do art. ${ }^{\circ} 73 .{ }^{\circ}$ do CPPT, encontrando-se esta última regulada nos artigos 77.0-A e 77. ${ }^{\circ}-\mathrm{B}$ do CPPT. No caso de existir fundamento para a cumulação de pedidos (art. ${ }^{\circ} 71 .{ }^{\circ}$ do CPPT) ou para a coligação de reclamantes (art. ${ }^{\circ} 72.0^{\circ}$ do CPPT), os interessados poderão requerer a apensação do seu pedido à reclamação apresentada em primeiro lugar, desde que (i) o procedimento se encontre na mesma fase; (ii) não exista prejuízo para a celeridade da decisão; (iii) se verifique uma identidade do tributo (entenda-se aqui a identidade da natureza do tributo); (iv) exista uma identidade do órgão competente para a decisão; e ( $v$ ) haja identidade dos fundamentos de facto e de Direito invocados - art. $74 .{ }^{\circ}$ do CPPT.

Quanto à entidade competente para a tomada de decisão, esta cabe ao dirigente do órgão periférico regional da área do domicílio ou sede do contribuinte, da situação dos bens ou da liquidação do imposto. Não existindo órgão periférico regional, a competência recai sobre o dirigente máximo do serviço (cfr. n. ${ }^{\circ} 1$ do art. ${ }^{\circ} 75 .{ }^{\circ}$ do CPPT). Em caso de dúvida sobre o órgão competente, será competente o órgão do domicílio fiscal do sujeito passivo - n. ${ }^{\circ} 4$ do art. ${ }^{\circ} 61 .{ }^{\circ}$ da LGT.

Proferida a decisão, sendo indeferida a reclamação graciosa, poderá haver lugar a impugnação judicial da mesma no prazo de três meses a contar da notificação do ato [art. ${ }^{102 .}{ }^{\circ}, \mathrm{n} .{ }^{\circ} 1$, alínea b) do CPPT] (indeferimento expresso); ou no prazo de três meses a contar da presunção de indeferimento tácito [art. ${ }^{\circ} 102 .{ }^{\circ}$, n. ${ }^{\circ} 1$, alínea d) do CPPT].

\subsection{Casos de reclamações graciosas necessárias previamente à via judicial}

Em alguns casos, a lei exige que, antes do recurso à via judicial, o contribuinte tenha que necessariamente apresentar uma reclamação

8 Acórdão do TCA Sul, 3/03/2016, processo n. ${ }^{\circ}$ 09266/16; acórdão do STA, 28/10/2009, processo n. 0 0595/09.

9 Ressalve-se que as regras estabelecidas no art. ${ }^{\circ} 75.0^{\circ}$ do CPPT não se aplicam à reclamação graciosa com fundamento em erro na classificação pautal, origem ou valor aduaneiro das mercadorias - cfr. n. ${ }^{\circ} 5$ do art. $075.0^{\circ}$ do CPPT. 
graciosa. A existência desta reclamação necessária justifica-se pela necessidade de filtrar certos atos previamente à via judicial10. Esta "filtragem administrativa" justifica-se "quando estão em causa atos que são da autoria do próprio sujeito passivo e nos quais a AT ainda não teve qualquer intervenção"11.

Há situações previstas na lei em que é necessário esgotar primeiramente a via administrativa antes de deduzir a impugnação judicial, a saber: (i) erro na autoliquidação (art. ${ }^{\circ} 131 .{ }^{\circ}$ do CPPT); (ii) erro na retenção na fonte (art. ${ }^{\circ} 132 .{ }^{\circ}$ do CPPT); (iii) erro nos pagamentos por conta (art. ${ }^{\circ}$ 133.0 do CPPT); (iv) erro em matéria de classificação pautal, origem ou valor aduaneiro das mercadorias (art. ${ }^{\circ} 133 .{ }^{\circ}-A$ do CPPT); (v) erro na quantificação da matéria tributável ou nos pressupostos de aplicação dos métodos indiretos (art. ${ }^{\circ} 117 .^{\circ}$ do CPPT). Estas situações configuram reclamações graciosas prévias ou necessárias:

(i) Em caso de erro na autoliquidação, a impugnação judicial será obrigatoriamente precedida de reclamação graciosa, dirigida ao dirigente máximo do órgão periférico regional, no prazo de dois anos após a apresentação da declaração (art. ${ }^{\circ} 131 .{ }^{\circ}$, n. ${ }^{\circ} 1$ do CPPT). Todavia, a reclamação graciosa deixa de ser necessária e passa a ser meramente facultativa se o fundamento para a impugnação for exclusivamente de natureza jurídica e a autoliquidação se basear em orientações genéricas, sendo aqui desnecessária uma nova pronúncia por parte da AT (art.o $131 .{ }^{\circ}$, n. ${ }^{\circ} 3$ do CPPT). De facto, havendo aqui uma orientação genérica, seria inútil apresentar uma reclamação graciosa uma vez que o entendimento da AT já está expresso na orientação genérica.

(ii) Tratando-se de erro na retenção na fonte, resultante de entrega de imposto superior ao retido, o substituto deve reclamar graciosamente e só após o indeferimento de tal reclamação é que poderá impugnar judicialmente, no prazo de dois anos a contar do termo do ano em que foi efetuado o pagamento indevido, de acordo com o art. ${ }^{\circ} 132 .{ }^{\circ}, \mathrm{n} .{ }^{\circ} 3$ do CPPT. No caso de o substituído pretender apresentar impugnação judicial, esta deverá ser precedida de reclamação graciosa, nos casos de retenção a título definitivo (n. ${ }^{\circ} 4$ do art. ${ }^{\circ} 132 .{ }^{\circ}$ do CPPT). Na situação de retenção a título de pagamento por conta, a reclamação só poderá ser levada a cabo após a liquidação definitiva, não sendo aquela necessária para efeitos de impugnação judicial (n. ${ }^{\circ} 4$ do art. ${ }^{\circ} 132 .{ }^{\circ}$ do CPPT).

(iii) No caso de erro nos pagamentos por conta do imposto devido a final (erro sobre os pressupostos da sua existência ou do seu quantitativo quando determinado pela AT - art. ${ }^{0} 133 .{ }^{\circ}$, n. ${ }^{\circ} 1$ do CPPT), a reclamação torna-se necessária, segundo o disposto no art. 0 133.0 do CPPT. Tais pagamentos por conta são suscetíveis de impugnação judicial, com fundamento em erro sobre os pressupostos da sua existência ou do seu

10 CARVALHO, C., "As reclamações prévias em matéria tributária", in Scientia Iuridica, Tomo LVII, n. 0 314, p. 285 e ss, 2008.

11 NETO, S. C. e TRINDADE, C. C., Contencioso Tributário - Procedimento, princípios e garantias, Vol. I, Almedina, p. 550, 2017; ROCHA, J. F., Lições de Procedimento e Processo Tributário, Coimbra Editora, p. 225-228, 2014. 
quantitativo, sendo que tal impugnação depende de prévia reclamação graciosa para o órgão periférico local da AT, no prazo de 30 dias após o pagamento indevido (n.o 2 do art.o 133.0 do CPPT). Decorridos 90 dias após a apresentação da reclamação sem que tenha sido deferida, considera-se esta tacitamente deferida (n. 04 do art. ${ }^{\circ} 133 .{ }^{\circ}$ do CPPT) (deferimento tácito).

(iv) Relativamente ao erro na classificação pautal, origem ou valor aduaneiro das mercadorias, o prévio esgotamento da via administrativa encontra-se consagrado no art. ${ }^{\circ} 133 .{ }^{\circ}-A$ do CPPT. Tal aplica-se sempre que o contribuinte pretenda contestar a legalidade dos atos de liquidação dos impostos especiais sobre o consumo, com fundamento na classificação pautal, origem ou valor aduaneiro das mercadorias. Nos restantes casos, em que o fundamento seja outro, o contribuinte pode optar pela reclamação graciosa ou pela impugnação judicial. Em matéria de classificação pautal, origem ou valor aduaneiro das mercadorias, os art. ${ }^{\circ} \mathrm{s}$ 73.0 , n.0 3 (sobre a competência para instauração e instrução do processo) e 75.0, n. 5 (sobre a entidade competente para a decisão da reclamação graciosa), ambos do CPPT, referem expressamente que não são de aplicar as normas gerais da reclamação graciosa, já que o legislador consagrou um regime específico para a reclamação graciosa em matérias relacionadas com a classificação pautal, a origem e o valor aduaneiro das mercadorias. Assim, a reclamação graciosa que tenha por base o fundamento aqui aludido deve ser apresentada junto do órgão periférico local que tenha praticado o ato de liquidação e remetida ao dirigente máximo do serviço para decisão - art. ${ }^{\circ} 77 .{ }^{\circ}-\mathrm{A}, \mathrm{n} .{ }^{\circ} 1$ do CPPT. Após a fase de instrução (descrita no n.0 2 do art.0 77.0-A do CPPT), o processo (em sentido físico) é remetido ao serviço central competente, num prazo de 15 dias, para que proceda à instrução complementar (se necessária), à análise do processo e à elaboração da proposta fundamentada de decisão - n. 03 do art. o 77. ०.-A do CPPT.

(v) Em caso de erro na declaração de rendimentos, a impugnação judicial é obrigatoriamente precedida de reclamação graciosa a apresentar no prazo de 2 anos, a contar do termo do prazo legal para a entrega da declaração - n.o 2 do art. ${ }^{\circ} 140.0^{\circ}$ do Código do Imposto sobre o Rendimento das Pessoas Singulares (CIRS).

De todo o exposto resulta que o sujeito passivo que pretenda impugnar judicialmente um ato de autoliquidação, de retenção na fonte ou de pagamento por conta deverá, previamente à impugnação, apresentar uma reclamação graciosa necessária, nos termos dos art. ${ }^{\circ} \mathrm{s} 131 .{ }^{\circ}$ a $133 .^{\circ}$ do CPPT.

\subsection{Articulação entre a reclamação graciosa e a impugnação judicial}

Pode acontecer que a reclamação graciosa seja apresentada em simultâneo com a impugnação judicial e com base nos mesmos fundamentos. Quando tal se verifica, deve ser dado prevalência ao processo judicial, conforme determina o art. ${ }^{\circ} 68 .^{\circ}, n^{\circ} 2$ do CPPT, que 
manda prosseguir o processo de impugnação judicial em vez do procedimento de reclamação graciosa.

Assim, se o contribuinte apresentar uma reclamação graciosa na pendência de impugnação judicial, a reclamação não é apreciada pela AT, sendo esta apensa ao processo de impugnação judicial12, cabendo então ao Tribunal apreciar as questões suscitadas na reclamação e na impugnação - cfr. art. 0111.0 , n. ${ }^{\circ} 4$ do CPPT. Esta apensação ao processo de impugnação judicial justifica-se por razões de economia processual, devendo as questões suscitadas no âmbito do procedimento de reclamação integrar a causa de pedir do processo de impugnação judicial (cfr. n.o 3 do art. ${ }^{\circ} 111 .^{\circ}$ do CPPT). Esta regra não se aplica à reclamação graciosa que tenha como fundamento em erro na classificação pautal, origem ou valor aduaneiro das mercadorias - cfr. n. ${ }^{0} 7$ do art. $073 .{ }^{\circ}$ do CPPT, encontrando-se esta última regulada nos artigos 77.0-A e 77.0-B do CPPT.

Se o procedimento de reclamação graciosa for apresentado depois de o processo de impugnação judicial ter dado entrada no Tribunal e com os mesmos fundamentos que os da impugnação, a reclamação graciosa deve então cessar os seus efeitos para que possa prosseguir a apreciação da legalidade tributária no âmbito do processo judicial.

Nos casos em que a impugnação judicial seja obrigatoriamente precedida de uma ação administrativa (reclamação graciosa necessária), o sujeito passivo deve primeiro esgotar a via administrativa ("reclamação graciosa necessária") antes de seguir a via judicial, devendo a impugnação ser obrigatoriamente precedida de reclamação graciosa, caso contrário o sujeito passivo não poderá lançar mão deste meio impugnatório.

Caso se verifique fundamento para a cumulação de pedidos (art. 071.0 do CPPT) ou para a coligação de reclamantes (art.o 72.0 do CPPT), os interessados poderão requerer a apensação do seu pedido à reclamação apresentada em primeiro lugar, desde que (i) o procedimento se encontre na mesma fase; (ii) não exista prejuízo para a celeridade da decisão; (iii) se verifique uma identidade do tributo (entenda-se aqui a identidade da natureza do tributo); (iv) exista uma identidade do órgão competente para a decisão; e (v) haja identidade dos fundamentos de facto e de Direito invocados - art. $074 .^{\circ}$ do CPPT.

\section{CONCLUSÃO}

Nas garantias que decorrem do procedimento tributário, a reclamação graciosa é, de todos os meios procedimentos, aquele que melhor assegurara a defesa dos direitos e interesses dos contribuintes. A reclamação graciosa pode ter por fundamento qualquer ilegalidade do ato de liquidação. Para prevenir e evitar ações ou omissões da administração fiscal, a reclamação graciosa apresenta-se como um importante meio de defesa, mas não tem o chamado efeito de caso julgado, que caracteriza a

12 NETO, S. C. e TRINDADE, C. C., Contencioso Tributário - Procedimento, princípios e garantias, Vol. I, Almedina, p. 537, 2017. 
fase judicial, e que garante neste aspeto uma maior defesa dos direitos dos contribuintes.

A reclamação graciosa tem por fundamento qualquer ilegalidade do ato tributário ou de ato de liquidação, sendo os fundamentos para a interposição da reclamação graciosa os mesmos aplicáveis à impugnação judicial, o que significa que importa bem distinguir um do outro para tentar garantir uma perfeita articulação entre os dois. O contribuinte pode, assim, entrar com uma reclamação graciosa ou optar pela via da impugnação contenciosa do ato tributário impugnado.

É precisamente este tipo de relação que importa delimitar, sobretudo naqueles casos em que, antes de recorrer à via judicial, o contribuinte tenha que necessariamente apresentar uma reclamação graciosa. Terá então o contribuinte que esgotar primeiramente a via administrativa antes de deduzir a impugnação judicial. A prévia interposição da reclamação necessária justifica-se pela necessidade de filtrar certos atos antes da via judicial. Só nos casos em que a lei não exige a reclamação necessária é que o contribuinte pode optar diretamente pela via da judicial.

Perante estas questões, o contribuinte deve estar suficientemente informado antes de decidir entre a reclamação graciosa e a impugnação judicial, o que obriga a que tenha, previamente à decisão de optar por um ou outro, um conhecimento de todos os factos e das questões de Direito que possam influenciar a sua decisão de optar por um ou outro tipo de mecanismo. Acontece que o contribuinte nem sempre dispõe de todos os elementos ou os conhecimentos necessários, sobretudo do ponto de vista jurídico, para a tomada de decisão, sobretudo porque a lei estabelece os mesmos fundamentos para uma e outra. Esta falta de distinção pode ser prejudicial para o contribuinte se não for devidamente aconselhado. Daí a necessidade de o legislador rever os fundamentos de uma e outra, bem como a articulação entre estes dois meios de defesa.

\section{BIBLIOGRAFIA}

CARVALHO, C., "As reclamações prévias em matéria tributária", in Scientia Iuridica, Tomo LVII, n. 314, 2008.

MARTINS, J. A. e ALVES, J. C., Procedimento e Processo Tributário: uma perspectiva prática, Almedina, 2015.

MORAIS, R. D., Manual de Procedimento e Processo Tributário, Almedina, 2012.

NETO, S. C. e TRINDADE, C. C., Contencioso Tributário - Procedimento, princípios e garantias, Vol. I, Almedina, 2017.

NETO, S. C. e TRINDADE, C. C., Contencioso Tributário - Processo, Arbitragem e Execução, Vol. II, Almedina, 2017.

ROCHA, J. F., Lições de Procedimento e Processo Tributário, Coimbra Editora, 2014.

SOUSA, J. L., Código de Procedimento e de Processo Tributário Anotado e Comentado, vol. I, Áreas Editora, 2011.

SOUSA, J. L., Código de Procedimento e de Processo Tributário Anotado e Comentado, vol. II, Áreas Editora, 2011. 